\title{
Human Development Index, Zakat Infaq Sadaqah, Income Inequality, and Poverty in Java
}

\author{
Mustapha Kemal Pasha ${ }^{1 *}$, and Abdul Aziz Nugraha Pratama ${ }^{2}$ \\ ${ }^{1}$ FEBI, IAIN Salatiga, Tantara Pelajar Street 02, Salatiga, Indonesia \\ ${ }^{2}$ FEBI, IAIN Salatiga, Tantara Pelajar Street 02, Salatiga, Indonesia
}

\begin{abstract}
This study aims to analyze how strong the influence of the Human Development Index (HDI), Zakat, Infaq, Shadaqah, and income inequality on poverty in 5 provinces in Java during one lustrum, namely 2015-2019. The island of Java includes 5 provinces, namely Banten, DKI Jakarta, West Java, Central Java and East Java. Eviews version 9 and SPSS version 13 were used as analysis tools. The results of this study prove that HDI has a negative and significant effect on poverty, ZIS has a positive but not significant effect on poverty, and income inequality has a positive but not significant effect on poverty.
\end{abstract}

\section{Introduction}

Poverty in Indonesia is real, which has been a problem since before Indonesia was colonized until now. This is expressed by several opinions from the national news and the opinions of thinkers. Said, (2020) stated that poverty in Indonesia has always been in the spotlight of public attention, both nationally and internationally, where poverty is an indicator of the country's economic prosperity.

The island of Java as the center of attention among other islands in Indonesia actually contributes to the largest poverty rate in Indonesia. The Central Statistics Agency (BPS) recorded the number of poor people in Indonesia reached around 24.79 million people or $9.22 \%$ in September 2019. That number experienced a decrease of 360 thousand people in March 2019 which was around 25.14 million people. Head of BPS Suhariyanto explained that of the total poor population, Java Island still has the highest number of other islands. There are about 12.56 million poor people in Java with a percentage rate of $8.29 \%$. In detail, the composition of the number of poor people on the island of Java is around 6.33 million people spread out in urban areas and around 6.21 million people spread out in rural areas (Nasution, 2020).

Islam teaches the use of public financial instruments that play a role in alleviating poverty in the form of Zakat, Infaq and Sadaqah (ZIS). Zakat is commanded by Allah swt through His Word in Q.S. At-Taubah verse 103. Zakat fitrah is distributed on Eid al-Fitr, many of the needy and poor can meet their needs on Eid day, so that they can feel happiness on the holiday like other Muslims. In zakat maal, many groups are entitled to receive zakat (asnaf) which can be helped financially. In addition to its function of increasing people's income, zakat also

\footnotetext{
* Corresponding author: pratama abdul@yahoo.com
} 


\section{$A \overline{I C B}$ Annual International Conference \\ on Islamic Economics and Business, 2021}

functions as productive zakat that is able to increase people's productivity. In infaq and Sadaqah, because the implementation is not limited in number or time, its existence is a helper for other people, be it small things to big things.

Some forms of giving in Islam other than zakat are infaq and Sadaqah. The distribution of ZIS funds by Dompet Dhuafa to Indonesia, especially in Java, changes every year. So that the number of zakat beneficiaries distributed by Dompet Dhuafa also changes every year.

The Human Development Index (HDI) in practice also plays a very important role in reducing poverty. Aspects of the HDI have been proposed by the UNDP agency which consist of life expectancy (in this case it means health), education and purchasing power (Beik, 2016). These three aspects increase the degree of human beings in terms of the quality of Human Resources.

Good quality human resources will support good productivity as well. These three aspects of HR affect a person's ability to explore their potential Lumbantoruan and Hidaya Prasetyoningrum (2018). So that with qualified potential, a person will become a productive human being who can save himself from poverty.

Income inequality is a condition that occurs naturally in which only a few people feel welfare. Income inequality is mostly caused by uneven development patterns. In Kuznets Theory, it is explained that the structure in the phases of development affects income disparities in the Kuncoro community (2006) in Febrianto (2016).

Various variables that affect poverty are urgent to be investigated so that obstacles can be found in alleviating it. This research was conducted because of the finding of gaps in the results of previous studies. Gaps also arise when there is a difference between what should happen and what is in fact (between das sollen and das sein) (Suryabrata, 2018).

This research was conducted with a focus on poverty, especially in Java. considering that Java is one of the most populous islands in Indonesia.

Research gap from previous studies. The following are some of the studies described below: First, research that proves that zakat, infaq and Sadaqah have a negative and significant effect on poverty in various districts and cities in Aceh Province (Yuliana, Yulfrita Adamy, 2019). Second, research that proves that zakat and infaq have a negative and significant effect on poverty in Aceh Province (Afifudin, 2019). Third, research that proves that zakat has a negative but not significant effect on poverty in Aceh Province (Tawakkal \& Sapha, 2018). Fourth, research that proves that HDI has a positive and significant effect on poverty in Jambi Province (Alhudhori, 2017). Fifth, research that proves that HDI has a negative and significant effect on poverty in Indonesia (Prasetyoningrum, 2018). Sixth, research that proves that HDI negative and significant effect on poverty in Indonesia (Suliswanto, 2010). Seventh, research that proves that inequality has a negative and significant effect on poverty in Bangka Belitung Province (Nisa et al., 2020). Eighth, research that proves that inequality has a negative and significant effect on poverty in South Sumatra Province (Rozali, 2020). Ninth, research that proves that inequality has a positive and significant impact on poverty in provinces throughout Indonesia (Hutagaol, 2019).

Various things to be answered in this research include: how does Zakat, Infaq and Sadaqah (ZIS) affect poverty in Java? How does the Human Development Index (HDI) level affect poverty in Java? How does income inequality affect poverty in Java?

\section{Result}

To test the stationarity of the data in this study, the Unit Root Test method was used using the Eviews version 9. The following is the stationarity test result of the Augmented DickeyFuller 1st Difference level. 
Table 1. Stationarity Test of the Augmented Dickey-Fuller Method Data Level 1st Difference.

\begin{tabular}{|c|c|c|}
\hline Variable & - t statistic & Probability \\
\hline Zakat Infaq Sadaqah (ZIS) & -5.887778 & 0.0001 \\
\hline Human Development Index (HDI) & -95.83560 & 0.0000 \\
\hline Inequality & -6.692458 & 0.0000 \\
\hline Poverty & -141.3254 & 0.0000 \\
\hline
\end{tabular}

From the stationarity test of the poverty variable using the Augmented Dickey-Fuller 1st Difference method shown in table 1 , it can be seen that the probability value of each variable is below the probability value of 0.05 . Because the probability value of all variables is less than 0.05 , then the data can be stated as stationary.

To find out whether the data from 5 provinces in Java are normally distributed, the Kolmogorov-Smirnov test method is used with the SPSS version 13 program.

Table 2. Data Normality Test Using Kolmogorov-Smirnov Test.

\begin{tabular}{|c|c|c|}
\hline \multicolumn{2}{|c|}{$\mathbf{N}$} & Unstandardized Residual \\
\cline { 2 - 3 } & & $\mathbf{2 5}$ \\
\hline \multirow{2}{*}{ Normal Parameters(a,b) } & Mean & .0000000 \\
\cline { 2 - 3 } & Std. Deviation & 1211773.66295245 \\
\hline \multirow{3}{*}{ Most Extreme Differences } & Absolute & .213 \\
\cline { 2 - 3 } & Positive & .120 \\
\cline { 2 - 3 } & Negative & -.213 \\
\hline \multicolumn{2}{|c|}{ Kolmogorov-Smirnov Z } & 1.063 \\
\hline \multicolumn{2}{|c|}{ Asymp. Sig. (2-tailed) } & .209 \\
\hline
\end{tabular}

The normality test results shown in Table 2 show the Asymp.Sig.(2-tailed) value of 0.209 or more than 0.05 . Thus, it can be seen that the data from 5 provinces in Java are normally distributed.

To see if there are symptoms of multicollinearity in the data of 5 provinces on the island of Java, the Multicollinearity test is used by looking at the Tolerance and VIF values using the SPSS version 13 program.

Table 3. Data Multicollinearity Test.

\section{Coefficients}

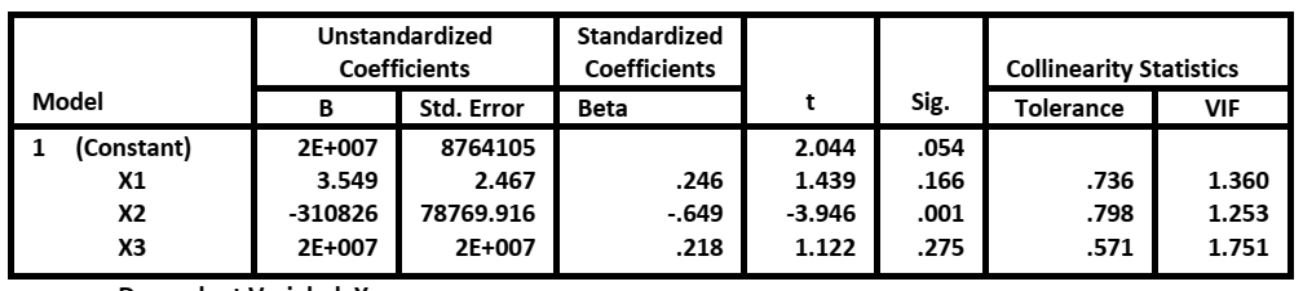

a. Dependent Variabel: $Y$ 


\section{$A I \overline{I E B} \quad$ Annual International Conference \\ on Islamic Economics and Business, 2021}

The results of the multicollinearity test shown in table 3 can be analyzed for the Tolerance and VIF values of each variable to determine whether each variable has symptoms of multicollinearity or not. From the SPSS version 13 output table above, it can be observed that the tolerance value of each variable is 0.736 for the $\mathrm{X} 1$ variable (ZIS), 0.798 for the $\mathrm{X} 2$ variable (IPM) and 0.571 for the X3 variable (inequality). Everything is greater than 0.1 . So it can be understood that the data does not occur multicollinearity. Then, if observed from the VIF value, each variable shows a value of 1.36 for the X1 variable (ZIS), 1.253 for the $\mathrm{X} 2$ variable (IPM) and 1.751 for the $\mathrm{X} 3$ variable (inequality). So it can be determined that the data really does not occur multicollinearity.

To test whether there are symptoms of heteroscedasticity in data from 5 provinces in Java, the Glejser Test method is used using the SPSS version 13 program.

Table 4. Data Heteroscedasticity Test Using Glejser Test.

\section{Coefficients}

\begin{tabular}{|c|c|c|c|c|c|}
\hline \multirow[b]{2}{*}{ Model } & \multicolumn{2}{|c|}{$\begin{array}{l}\text { Unstandardized } \\
\text { Coefficients }\end{array}$} & \multirow{2}{*}{$\begin{array}{l}\text { Standardized } \\
\text { Coefficients } \\
\text { Beta }\end{array}$} & \multirow[b]{2}{*}{$t$} & \multirow[b]{2}{*}{ Sig. } \\
\hline & B & Std. Error & & & \\
\hline 1 (Constant) & $1 E+007$ & 3471740 & & 4.158 & .000 \\
\hline $\mathrm{X} 1$ & -4.291 & .977 & -.715 & -4.390 & .000 \\
\hline $\mathrm{X} 2$ & -80263.1 & 31203.263 & -.402 & -2.572 & .018 \\
\hline X3 & $-2 E+007$ & 6839781 & -.513 & -2.774 & .012 \\
\hline
\end{tabular}

a. Dependent Variabel: Abs_RES

The following shows the scatterplot test of 5 provinces in Java Island.

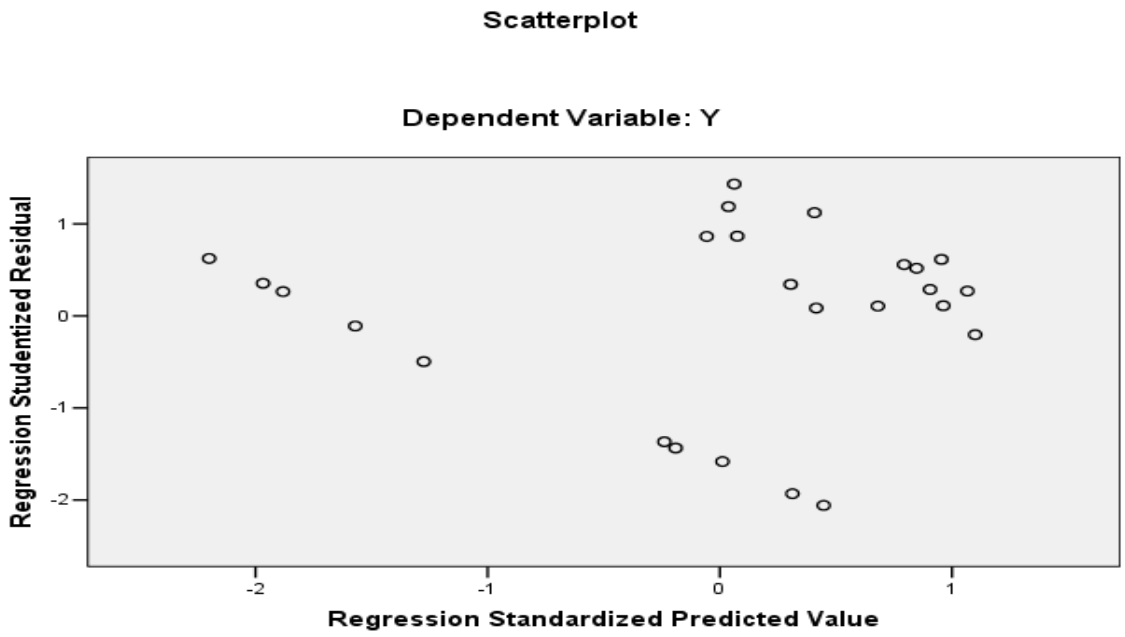

Fig.1. Data Scatterplot Test.

From Figure 1 it can be seen, the points in the graph are scattered irregularly or without a pattern. Thus, it can be understood that this regression model is free from heteroscedasticity symptoms. 


\section{$A I C \overline{I E B}$ Annual International Conference \\ on Islamic Economics and Business, 2021}

The next step is testing the classical assumption of autocorrelation, because the data in this study is time series data. Data from 5 provinces in Java was tested for autocorrelation using the Durbin Watson Test method using the SPSS version 13 program. Before looking at the Durbin-Watson values, first determine the values of dU, dL, 4-dU and 4-dL as a benchmark in determining autocorrelation symptoms. these are the limits of dU, dL, 4-dU and 4-dL as the determination of the autocorrelation test in this test.

Table 5. Durbin-Watson Test Table.

\begin{tabular}{|c|c|c|c|c|}
\hline $\begin{array}{c}\text { There is a } \\
\text { negative } \\
\text { autocorrelation }\end{array}$ & $\begin{array}{l}\text { Cannot be } \\
\text { determined }\end{array}$ & $\begin{array}{l}\text { There are no } \\
\text { symptoms of } \\
\text { autocorrelation }\end{array}$ & $\begin{array}{l}\text { Cannot be } \\
\text { determined }\end{array}$ & $\begin{array}{c}\text { There is a } \\
\text { positive } \\
\text { autocorrelation }\end{array}$ \\
\hline & $\begin{array}{c}\mathrm{dL} \\
1,0381\end{array}$ & $\begin{array}{c}\mathrm{dU} \\
1,7666\end{array}$ & $\begin{array}{c}4-\mathrm{dU} \\
2,2334\end{array}$ & $\begin{array}{c}4-\mathrm{dL} \\
2,9619\end{array}$ \\
\hline
\end{tabular}

The following shows the data autocorrelation test.

Table 6. Durbin-Watson test results.

\begin{tabular}{|c|c|c|c|c|c|}
\hline Model & R & R Square & $\begin{array}{c}\text { Adjusted R } \\
\text { Square }\end{array}$ & $\begin{array}{c}\text { Std. Error of } \\
\text { the Estimate }\end{array}$ & Durbin-Watson \\
\hline 1 & $.754(\mathrm{a})$ & .568 & .482 & 1327431.53958 & 1.914 \\
\hline
\end{tabular}

The Durbin-Watson value of 1.914 obtained by testing using the SPSS version 13 program shown in Table 6 is between the values of dU (1.7666) and 4-dU (2.2334). Based on the provisions of the autocorrelation test by looking at the position of the Durbin-Watson value against the $\mathrm{dU}$ and $\mathrm{dL}$ ranges, the data in this study can be declared free of autocorrelation symptoms because the Durbin-Watson value is between $\mathrm{dU}$ and 4-dU values.

After the data is free from the symptoms of classical assumptions, the next step is the data can be tested for regression which includes the F test, $\mathrm{t}$ test and $\mathrm{R} 2$ test.

Table 7 below is the output of SPSS Anova Test or F test to determine the effect between the independent and dependent variables.

Table 7. F Test (Anova Test).

ANOVR ${ }^{b}$

\begin{tabular}{|c|c|c|c|c|c|c|}
\hline \multicolumn{2}{|c|}{ Model } & $\begin{array}{l}\text { Sum of } \\
\text { Squares }\end{array}$ & df & Mean Square & $\mathrm{F}$ & Sig. \\
\hline \multirow[t]{3}{*}{1} & Regression & $5 E+013$ & 4 & $1.159 E+013$ & 6.580 & $.002^{5}$ \\
\hline & Residual & $4 E+013$ & 20 & $1.762 E+012$ & & \\
\hline & Total & $8 \mathrm{E}+013$ & 24 & & & \\
\hline
\end{tabular}

a. Predictors: (Constant), X4, X1, X3, X2

b. Dependent Variable: $Y$

From the results of data processing Anova Test or F Test in Table 7 can be observed on the value of Sig. The Sig value shows the number 0.002 with an F coefficient value of 6.58 . It means that it can be said that the independent variables which include X1 (ZIS), X2 (IPM) 
and X3 (inequality) simultaneously affect the $\mathrm{Y}$ variable (poverty) positively and significantly.

Table 8 is the output of SPSS t test of the direct effect between each independent variable on the dependent variable.

Table 8. T Test.

\section{Coefficients}

\begin{tabular}{|c|c|c|c|c|c|}
\hline \multirow[b]{2}{*}{ Model } & \multicolumn{2}{|c|}{$\begin{array}{l}\text { Unstandardized } \\
\text { Coefficients }\end{array}$} & \multirow{2}{*}{$\begin{array}{l}\text { Standardized } \\
\text { Coefficients } \\
\text { Beta }\end{array}$} & \multirow[b]{2}{*}{$\mathrm{t}$} & \multirow[b]{2}{*}{ Sig. } \\
\hline & B & Std. Error & & & \\
\hline 1 (Constant) & $2 \mathrm{E}+007$ & 8764105 & & 2.044 & .054 \\
\hline $\mathrm{X} 1$ & 3.549 & 2.467 & .246 & 1.439 & .166 \\
\hline $\mathrm{X} 2$ & -310826 & 78769.916 & -649 & -3.946 & .001 \\
\hline X3 & $2 \mathrm{E}+007$ & $2 \mathrm{E}+007$ & .218 & 1.122 & .275 \\
\hline
\end{tabular}

a. Dependent Variabel: $Y$

The results of SPSS version 13 data processing in Table 8 can be taken several values to determine the effect of each independent variable on the dependent variable. Variable X1 (ZIS) has a sig value of 0.166 with a coefficient of 1.439 . Then, the variable X2 (IPM) has a sig value of 0.001 with a coefficient of -3.946 . Meanwhile, the X3 (inequality) variable has a sig value of 0.275 with a coefficient of 1.122 . Thus, it can be concluded that the variable $\mathrm{X} 1$ (ZIS) has a positive but not significant effect on the $\mathrm{Y}$ variable (poverty) with a large effect of 1.439. Then the X2 variable (IPM) has a negative and significant effect on the $\mathrm{Y}$ variable (poverty) with a large effect of -3.946 . Then the $\mathrm{X} 3$ variable (inequality) has a positive but not significant effect on the $\mathrm{Y}$ variable (poverty) with a large effect of 1.122.

Table 9 below is the output of SPSS version 13 R2 test to test the feasibility of the regression model.

Table 9. R2 test.

\begin{tabular}{|c|c|c|c|c|}
\hline Model & R & R Square & $\begin{array}{c}\text { Adjusted R } \\
\text { Square }\end{array}$ & $\begin{array}{c}\text { Std. Error of } \\
\text { the Estimate }\end{array}$ \\
\hline 1 & $.754(\mathrm{a})$ & .568 & .482 & 1327431.53958 \\
\hline
\end{tabular}

The results of data processing of Data Fit Test or R2 Test in Table 9 can be observed the value of $\mathrm{R}$ Square. The value of $\mathrm{R}$ Square shows a value of 0.568 . That means, the influence of the variables X1 (ZIS), X2 (IPM) and X3 (inequality) on the variable Y (poverty) is $56.8 \%$. So that $43.2 \%$ is influenced by other variables outside the regression model.

From the results of the regression test of the independent and dependent variables in Table 9 , each hypothesis can be analyzed and interpreted. The following describes the analysis and discussion of each hypothesis from the results of the regression test above.

From the results of the regression analysis in Table 9, it can be seen that the significance value of $\mathrm{X} 1$ is 0.564 and the t-count value of $\mathrm{X} 1$ is 1.439 . The significance value of $\mathrm{X} 1$ is greater than the significance level of (0.05). Because the significance value of the $\mathrm{X} 1$ variable 
exceeds the significance level of , the effect of ZIS on poverty is not significant. Meanwhile, the t-count value of $\mathrm{X} 1$ which is 1.439 indicates that the value of $\mathrm{X} 1$ 's influence on $\mathrm{Y}$ is 1.439. That means, ZIS has a positive effect on poverty. If it is related to field implementation, it can be understood that every increase in the recipient of ZIS funds in 5 provinces in Java by 1 person will neither increase nor decrease the number of poor people. If there is an increase in the number of poor people, the increase is not drastic, which is only 1,439 people. From the significance value of $\mathrm{X} 1$ and t-count of $\mathrm{X} 1$ it can be concluded that the effect of ZIS on poverty is positive but not directly significant.

From the results of the regression analysis in Table 9, it can be seen that the significance value of $\mathrm{X} 3$ is 0.001 and the t-count of $\mathrm{X} 3$ is -3.946 . The significance value of $\mathrm{X} 3$ is smaller than the significance level of (0.05). Because the significance value of the $\mathrm{X} 3$ variable is less than the significance level, the impact of HDI on poverty is significant. While the t-count value of $\mathrm{X} 3$ which is -3.946 indicates that the value of $\mathrm{X} 3$ 's influence on $\mathrm{Y}$ is -3.946 . That means, HDI has a negative effect on poverty. If it is related to field implementation, it can be understood that every increase in HDI in 5 provinces in Java by 1 will be able to reduce the number of poor people in 5 provinces in Java by 3,946 people. From the significance value of X3 and t-count of X3 it can be concluded that the effect of HDI on poverty is negative and significant.

From the results of the regression analysis in Table 9, it can be seen that the significance value of $\mathrm{X} 4$ is 0.275 and the t-count value of $\mathrm{X} 4$ is 1.122 . The significance value of $\mathrm{X} 4$ is greater than the significance level of (0.05). Because the significance value of the $\mathrm{X} 4$ variable exceeds the significance level of , the effect of inequality on poverty is not significant. The $\mathrm{t}$-count value of $\mathrm{X} 4$ which is 1.122 indicates that the value of $\mathrm{X} 4$ 's influence on $\mathrm{Y}$ is 1.122. That means, inequality has a positive effect on poverty. If it is related to field implementation, it can be understood that every increase in the Gini Ratio Index from 5 provinces in Java by 1 , it will neither increase nor reduce the number of poor people. Even if it is able to increase the number of poor people, the increase is not drastic, namely as many as 0.573 people. From the significance value of X4 and $t$ arithmetic of $\mathrm{X} 4$ it can be concluded that the effect of inequality on poverty is positive but not significant.

\section{Discussion}

From the results of the regression test of the independent and dependent variables, each hypothesis can be analyzed and interpreted as follows:

\subsection{Effect of ZIS (X1) on Poverty (Y)}

From the results of the regression analysis in Table 8 , it can be seen that the significance value of $\mathrm{X} 1$ is 0.564 and the $\mathrm{t}$-count value of $\mathrm{X} 1$ is 1.439 . The significance value of $\mathrm{X} 1$ is greater than the significance level of (0.05). Because the significance value of the X1 variable exceeds the significance level of , the effect of ZIS on poverty is not significant. While the tcount value of X1 which is 1.439 indicates that the value of X1's influence on Y is 1.439. That means, ZIS has a positive effect on poverty. If it is related to field implementation, it can be understood that every increase in the recipient of ZIS funds in 5 provinces in Java by 1 person will neither increase nor decrease the number of poor people. If there is an increase in the number of poor people, the increase is not drastic, which is only 1,439 people. From the significance value of X1 and t-count of X1 it can be concluded that the effect of ZIS on poverty is positive but not significant. 


\section{$A I \overline{C E B} \quad$ Annual International Conference \\ on Islamic Economics and Business, 2021}

Thus, the results of the analysis of this hypothesis are not in line with the results of research from three previous studies, namely the research conducted by Yuliana et al. (2019), the research conducted by Afifudin (2019), and the research conducted by Afifudin (2019). performed by Tawakkal \& Sapha (2018). Research conducted by Yuliana et al. (2019) analyzed the effect of zakat, infaq and Sadaqah (ZIS) funds on regencies and cities in Aceh province. city in Aceh Province. Likewise, research conducted by Toha Afifudin and Nurma Sari in 2019 analyzing the effect of zakat and infaq on poverty reduction in Aceh Province in the 2007-2017 period resulted in research findings that zakat had a negative and significant effect on poverty in Aceh Province. While the research conducted by Muhammad Iqbal Tawakkal and Diana Sapha A.H. in 2018 analyzing the effect of zakat on poverty in Aceh Province is different from the two previous studies. Research conducted by Tawakkal \& Sapha (2018) proves that zakat has a negative but not significant effect on poverty in Aceh Province. Thus, the findings of this study contradict H1 which states that ZIS has a negative and significant effect on poverty.

\subsection{Effect of HDI (X2) on Poverty (Y)}

From the results of the regression analysis in Table 8 . above, it can be seen that the significance value of $\mathrm{X} 2$ is 0.001 and the t-count of $\mathrm{X} 2$ is -3.946 . The significance value of $\mathrm{X} 2$ is smaller than the significance level of (0.05). Because the significance value of the X2 variable is less than the significance level, the impact of HDI on poverty is significant. While the t-count value of $\mathrm{X} 3$ which is -3.946 indicates that the value of $\mathrm{X} 2$ 's influence on $\mathrm{Y}$ is 3.946. That means, HDI has a negative effect on poverty. If it is related to field implementation, it can be understood that every increase in HDI in 5 provinces in Java by 1 will be able to reduce the number of poor people in 5 provinces in Java by 3,946 people. From the significance value of X2 and t-count of X2, it can be concluded that the effect of HDI on poverty is negative and significant.

Thus, the results of the analysis of this hypothesis are in line with the results of research conducted by research conducted by Ari Kristin Prasetyoningrum and U. Sulia Sukmawati in 2018, as well as research conducted by Muhammad Sri Wahyudi Suliswanto in 2010 but not in line with research conducted by Alhudhori (2017). Research conducted by Prasetyoningrum \& Sukmawati (2018), analyzed the effect of HDI, economic growth and unemployment on poverty in Indonesia. Likewise with the research conducted by Muhammad Sri Wahyudi Suliswanto in 2010 which analyzed the effect of GDP and HDI on poverty in Indonesia. The results of this study prove that HDI has a negative and significant effect on poverty in Indonesia. In contrast to the two previous studies, the research conducted by M. Alhudori produced different findings. Research conducted by Alhudhori (2017) analyzed the effect of HDI, GRDP and unemployment on the poor in Jambi Province. Thus, the findings of this study prove $\mathrm{H} 3$ which states that HDI has a positive and significant effect on poverty.

\subsection{Pengaruh Ketimpangan (X3) terhadap Kemiskinan (Y)}

From the results of the regression analysis in Table 9, it can be seen that the significance value of $\mathrm{X} 3$ is 0.275 and the t-count value of $\mathrm{X} 3$ is 1.122 . The significance value of $\mathrm{X} 3$ is greater than the significance level of (0.05). Because the significance value of the $\mathrm{X} 3$ variable exceeds the significance level of , the effect of inequality on poverty is not significant. While the $\mathrm{t}$-count value of $\mathrm{X} 3$ which is 1.122 indicates that the value of $\mathrm{X} 3$ 's influence on $\mathrm{Y}$ is 1.122. That means, inequality has a positive effect on poverty. If it is related to field implementation, it can be understood that every increase in the Gini Ratio Index from 5 
provinces in Java by 1, it will neither increase nor reduce the number of poor people. Even if it is able to increase the number of poor people, the increase is not drastic, namely as many as 0.573 people. From the significance value of $\mathrm{X} 3$ and $\mathrm{t}$-count of $\mathrm{X} 3$ it can be concluded that the effect of inequality on poverty is positive but not significant.

Thus, the results of the analysis of this hypothesis are not in line with the results of the two previous studies, namely the research conducted by Khoirun Nisa, Ayu Wulandari and Rini Luciani Rahayu in 2020, and the research conducted by Muhammad Rozali in 2020. The research conducted by Nisa et al. (2020), analyzed the effect of income inequality on poverty in Bangka Belitung Province in 2009-2018 which resulted in the finding of inequality having a negative and significant effect on poverty in Bangka Belitung Province. Likewise with research conducted by Rozali (2020), who analyzed the factors that influence the inequality of income distribution and its implications for poverty in South Sumatra Province. The results of this study are also not in line with research conducted by David Togar Hutagaol in 2019 which analyzed the effect of population growth rates, economic growth, HDI, income inequality and unemployment rates on poverty in provinces throughout Indonesia which proved that inequality has a positive and significant effect on poverty in Indonesia. provinces throughout Indonesia. The results of this study prove that inequality has a negative and significant effect on poverty in South Sumatra Province. Thus, the findings of this study contradict $\mathrm{H} 4$ which states that inequality has a positive and significant effect on poverty.

\section{Conslusion}

From the results of various analyzes that have been carried out in this study regarding the effect of Zakat Infak Sadaqah (ZIS), Human Development Index (IPM) and inequality, it can be seen that Zakat Infak Sadaqah (ZIS) has a positive but not significant effect on poverty, the Human Development Index ( HDI) has a negative and significant effect on poverty, and inequality has a positive but not significant effect on poverty.

\section{References}

Afifudin, T. dan N. S. (2019). Pengaruh Zakat dan Infaq terhadap Penurunan Kemiskinan di Aceh Periode 2007-2017. Ebis, 4, 34-51.

Alhudhori, M. (2017). Pengaruh IPM, PDRB Dan Jumlah Pengangguran terhadap Penduduk Miskin Di Provinsi Jambi. EKONOMIS : Journal of Economics and Business, 1(1), 113. https://doi.org/10.33087/ekonomis.v1i1.12

Beik, I. S. dan L. D. A. (2016). Ekonomi Pembangunan Syariah (1st ed.). Rajagrafindo Persada.

Febrianto, R. (2016). Ketimpangan Pendapatan Antar Daerah Di Provinsi Jawa Tengah Tahun 2011-2014 Jurnal Ilmiah. Jurnal Ilmiah, 1-13.

Hutagaol, D. T. (2019). Analisis Pengaruh Tingkat Pertumbuhan Penduduk, Pertumbuhan Ekonomi , IPM , Ketimpangan Distribusi Pendapatan Dan Tingkat Pengangguran Terhadap Kemiskinan di Provinsi Se-Indonesia. Tesis, 1-92.

Nasution, D. D. dan N. Z. (2020, July). Angka Kemiskinan di Indonesia Melonjak. Republika, 1.

Nisa, K., Wulandari, A., \& Rahayu, R. L. (2020). Pengaruh ketimpangan pendapatan terhadap kemiskinan di Provinsi Kepulauan Bangka Belitung tahun 2009-2018. Sorot, 15(1), 55-63. https://doi.org/10.31258/sorot.15.1.55-63

Prasetyoningrum, A. K. (2018). Analisis Pengaruh Indeks Pembangunan Manusia (Ipm), 


\section{$A \mathrm{IC} \quad$ Annual International Conference \\ on Islamic Economics and Business, 2021}

Pertumbuhan Ekonomi, Dan Pengangguran Terhadap Kemiskinan Di Indonesia. Equilibrium: Jurnal Ekonomi Syariah, 6(2), 217. https://doi.org/10.21043/equilibrium.v6i2.3663

Prasetyoningrum, A. K., \& Sukmawati, U. S. (2018). Analisis Pengaruh Indeks Pembangunan Manusia (Ipm), Pertumbuhan Ekonomi, Dan Pengangguran Terhadap Kemiskinan Di Indonesia. Equilibrium: Jurnal Ekonomi Syariah, 6(2), 217. https://doi.org/10.21043/equilibrium.v6i2.3663

Rozali, M. (2020). Faktor Faktor yang Mempengaruhi Ketimpangan Distribusi Pendapatan dan Implikasinya terhadap Kemiskinan di Propinsi Sumatera Selatan. Jurnal Ekonomi, 22(1), 1-16.

Said, Z. (2020, February). Masalah Kronis Kemiskinan di Indonesia. Media Sulsel, 1.

Suliswanto, M. S. W. (2010). Pengaruh produk domestik bruto (PDB) dan indeks pembangunan manusia (IPM) terhadap Angka Kemiskinan di Indonesia. Jurnal Ekonomi Pembangunan, 8(2), 357-366.

Suryabrata, S. (2018). Metodologi Penelitian. Rajagrafindo Persada.

Tawakkal, M. I., \& Sapha, D. (2018). Pengaruh Zakat Terhadap Kemiskinan Di Provinsi Aceh. Jurnal Ilmiah Mahasiswa (JIM), 3(4), 704-711.

Yuliana, Yulfrita Adamy, dan C. A. (2019). Pengaruh Dana Zakat Infak dan Sedekah (ZIS) terhadap Kemiskinan di Kabupaten/Kota di Provinsi Aceh. Ekapi, 6(2442-7411), 203214.

Yuliana, Y., Adamy, Y., \& Adhila, C. (2019). Pengaruh Dana Zakat Infak dan Sedekah (ZIS) Terhadap Kemiskinan Di Kabupaten/Kota Provinsi Aceh. Jurnal Ekonomi Dan Kebijakan Publik Indonesia, 6(2), 203-214. 